Life Sciences Contribution

Royal Ontario Museum

88

A Contribution to the Biology of Caddisflies (Trichoptera) in Temporary Pools

Glenn B. Wiggins

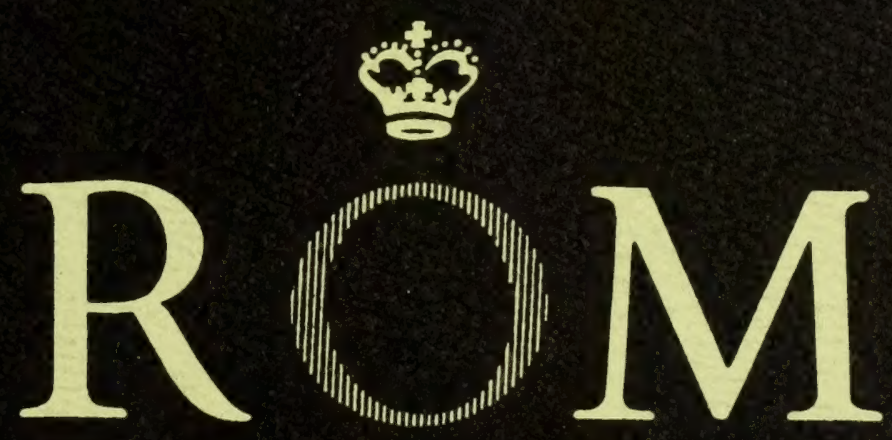


Digitized by the Internet Archive in 2011 with funding from University of Toronto 
LIFE SCIENCES CONTRIBUTIONS

ROYAL ONTARIO MUSEUM

NUMBER 88

GLENN B. wiggins AContribution to the Biology of Caddisflies (Trichoptera) in Temporary Pools 


\section{ROYAL ONTARIO MUSEUM \\ PUBLICATIONS IN LIFE SCIENCES}

The Royal Ontario Museum publishes three series in the Life Sciences:

LIFE SCIENCES CONTRIBUTIONS, a numbered series of original scientific publications, including monographic works.

LIFE SCIENCES OCCASIONAL PAPERS, a numbered series of original scientific publications, primarily short and usually of taxonomic significance.

LIFE SCIENCES MISCELLANEOUS PUBLICATIONS, an unnumbered series of publications of varied subject matter and format.

All manuscripts considered for publication are subject to the scrutiny and editorial policies of the Life Sciences Editorial Board, and to review by persons outside the Museum staff who are authorities in the particular field involved.

\section{LIFE SCIENCES EDITORIAL BOARD,}

\section{Chairman: R. L. PETERSON}

Editors: J. R. TAMSITT, Editor

D. BARR, Associate Editor

E. J. CRossman, Associate Editor

GLENN B. WIGGINS is Curator of the Department of Entomology and Invertebrate Zoology, Royal Ontario Museum, and Professor in the Department of Zoology, University of Toronto.

PRICE： $\$ 2.00$

(o) The Royal Ontario Museum, 1973

100 Queen's Park, Toronto, Canada

PRINTED AT THE BRYANT PRESS LIMITED 


\title{
A Contribution to the Biology of Caddisflies (Trichoptera) in Temporary Pools
}

\begin{abstract}
The study initiates an examination of the operation and evolution of adaptations that enable certain species of Trichoptera to live in temporary pools. Two types of habitats are recognized and defined: temporary vernal pools and temporary autumnal pools. Species of three families are involved: the Limnephilidae, Phryganeidae, and Polycentropodidae.

For the Limnephilidae, observations on the life history of Limnephilus indivisus Walker and L. submonilifer Walker in temporary pools in Ontario are outlined. Adaptations found to be important for these species in temporary vernal pools include diapause, oviposition apart from water, and a gelatinous matrix that protects the eggs from desiccation and freezing. Based on a review of available data on ovipositional characteristics in the Limnephilidae, some general evolutionary patterns are considered; species in the subfamilies Limnephilinae and Dicosmoecinae appear to have invaded temporary pools independently.

In the Phryganeidae, available evidence suggests that only the European species Trichostegia minor (Curtis) can survive in temporary vernal pools.

In the Polycentropodidae, three species of Polycentropus occur in the temporary vernal pools studied in Ontario. The adaptive mechanisms involved are not yet understood.
\end{abstract}

\section{Introduction}

Evolution of mechanisms enabling insect groups characteristic of permanent waters to live in temporary pools has evidently not been a common phenomenon, and thus its successful achievement in certain of the Trichoptera seems worthy of consideration. Although the literature on the biology of caddisflies contains a number of isolated observations relevant to this topic, few attempts at synthesis have been made.

The purpose of this paper is to initiate an examination of available data, with the ultimate objective of gaining an understanding of the operation and evolution of adaptations that have enabled certain caddisflies to live in temporary pools. New observations are outlined and integrated with published data, but much has still to be learned.

Caddisfly larvae of three families are now known to be inhabitants of temporary pools in the northern hemisphere: the Limnephilidae, Phry- 
ganeidae, and Polycentropodidae. Observations and discussion for each of these families are treated separately in this paper after some general considerations.

\section{Definitions and Methods}

Several terms in this paper are used in a special sense. A temporary pool is here considered to be an accumulation of surface water in a basin that has no surface outlet, the water disappearing from the surface for a part of each year. The aquatic habitats being considered represent, then, one category of seasonally astatic waters that might be more precisely termed annual temporary pools. So restricted, temporary pools still cover a wide range of habitat diversity, and a further subdivision is important, even among those pools that retain surface water for a period sufficiently long to sustain caddis larvae through their development. The majority of pools involved in this study receive their surface water from rain and melting snow - usually beginning some time in March in southern Ontario. Water levels decline as summer approaches; basins are empty by June or July and remain so until the following March, thus providing an annual cycle of approximately 4 months of water and 8 months of drought. Pools of this type are here designated temporary vernal pools since surface water terminating the dry period is replenished in the spring.

Owing to the nature of the substrata or to the abundance of rainfall, some pool basins retain surface water in autumn, and thus the drought period is terminated much earlier than in temporary vernal pools. Pools of this type are here designated temporary autumnal pools and in southern Ontario persist from about October through July, a period of about 9 months, with a summer drought of about 3 months.

In years of heavy precipitation, basins of some temporary pools retain at least some surface water during periods when they would be dry in other years. Therefore, in successive years, a temporary vernal pool could be followed by a temporary autumnal pool in the same basin; or the same basin might retain surface water for a full year, thereby meeting the requirements of a permanent pool for most of the animal inhabitants. For this reason, designation of pools as temporary, and as particular types of temporary pools, is based on knowledge of water levels in the basin of the pool concerned for the summer and autumn immediately preceding the observations.

The term surface water used in the preceding definitions means water lying on the surface of the pool basin in depths sufficient to sustain a normal range of activities by aquatic macroinvertebrates such as insect larvae. After surface water finally disappears from view, in the declining stages of a temporary pool, soil in the basin remains wet for a time, providing sufficient moisture to sustain developing stages of some aquatic organisms for short periods. In this way, pupae of temporary-pool Trichoptera continue to develop and emerge successfully as adults, even after surface water has disappeared from the basin.

Eggs of species in families of case-making Trichoptera such as the Limnephilidae and the Phryganeidae are enclosed in a gelatinous matrix, the 
eggs and matrix comprising an egg mass. Although egg masses of most species of caddisflies are deposited in water, this paper is largely concerned with species that do not oviposit in water - oviposition apart from water is the term used here. Oviposition apart from water may occur even though water is present: (1) oviposition above water is the term used when an egg mass is deposited vertically above water, and larvae could drop or otherwise descend directly into water below; (2) oviposition away from water is the term used when an egg mass is deposited on a substrate that is horizontally as well as vertically displaced from water, and normally larvae would have to crawl to water after leaving the egg matrix. In both instances, water levels could, of course, rise to flood the matrix with its newly hatched larvae, or rain could wash larvae into the water. Oviposition apart from water can also occur when there is no surface water, and this is the usual situation for caddisfly species ovipositing in basins of temporary vernal pools.

Most observations reported here have been made since 1959 on the faunae of a series of temporary pools in two areas of southern Ontario: (1) within a 70-mile radius of Toronto; and (2) in Algonquin Provincial Park, 185 miles north of Toronto. The pools ranged in longest dimension from approximately $3-25 \mathrm{~m}$ and in maximum depth from approximately $30-150 \mathrm{~cm}$. Some pools were heavily shaded by surrounding trees; others had few trees around them.

In the Toronto area, pools are designated as Kendal I and II in Durham County; as Vandorf I, II, and III, and Aurora IV, V, VI and VII in York Country. All pools were located on the interlobate moraine passing parallel to the north shore of Lake Ontario, in cleared agricultural areas of the mixed deciduous-coniferous forest characteristic of most of south-central Ontario.

In Algonquin Provincial Park, pools studied for short intervals in 1959 and 1960 were located on the Precambrian Shield in the general vicinity of Lake Opeongo. Basins of these pools lay in glacial deposits.

Larvae were associated with adults by rearing in the laboratory using techniques described by Wiggins (1959) or by collecting mature pupae in which diagnostic characters of the adults were sufficiently well developed for species identification. Eggs were assigned to species on the basis of known larvae reared from them.

Other observations were made in field studies in various other habitats in Ontario, Oregon, and Minnesota.

\section{Role of Diapause}

Studies by Novak and Sehnal $(1963,1965)$ in Czechoslovakia reveal that diapause is an important adaptation for species of the Limnephilidae and Phryganeidae occurring in temporary pools. Their work demonstrated that the two generations per year traditionally attributed to some European species of Limnephilus and of several other genera was an erroneous interpretation. These species have only one generation per year, but adults live for periods of 4 to 6 months - from emergence in late spring until oviposition in late summer. Sexual maturity in these long-lived adults is delayed by a diapause that is terminated by the appearance of shorter days as autumn approaches - normal photoperiod control but evidently with some influence 
by temperature as well. The larval stages of the species that Novak and Sehnal studied occur in temporary pools. They found adults living in concealment at the edges of woods in summer and flying in the vicinity of pool basins when emerging in spring or ovipositing in autumn. Bournaud (1971) made observations in France demonstrating diapause in adults of Micropterna nycterobia (McLachlan), M. testacea (Gmelin), and Stenophylax permistus McLachlan that aestivate in caves. Larvae of these species inhabit cool streams. Work by Crichton in Great Britain showed that limnephilid caddisflies of many species have a long adult life, dispersing widely as adults (1961); and that length of their flight periods indicated three categories of life history, one probably involving a diapause and two without a diapause (1971). Crichton also demonstrated (1957) that mouth parts of the adults are suited for feeding upon nectar and other liquids, thus giving them access to nutrients necessary to sustain these habits.

In providing the functional explanation for the long-lived adult caddisflies, Novak and Sehnal $(1963,1965)$ stated that the summer diapause is the means by which Trichoptera of temporary waters survive the dry period. For pools that are replenished with surface water in autumn, i.e., temporary autumnal pools as defined above, as those studied by Novak and Sehnal were, this is largely true. But this explanation does not account wholly for the survival of Trichoptera in pools that are without surface water until the following spring, i.e., temporary vernal pools as defined above. In fact, summer diapause in the adult stage postpones larval development until autumn - approximately 4 months. Observations on temporary-pool Trichoptera in Ontario, outlined below, demonstrate that the life cycle in species of the Limnephilidae inhabiting temporary vernal pools can be suspended during the entire winter until surface water is available in the spring - an additional interval of approximately 6 months. These data indicate that this additional suspension of the life cycle has been brought about through evolution of oviposition apart from water and of a gelatinous egg-matrix that is highly resistant to desiccation and freezing. Observations by Décamps (1967) on the life history of Limnephilus bipunctatus Curtis in France support this interpretation.

\section{Limnephilidae}

In the temporary pools studied, limnephilid species were Limnephilus indivisus Walker, L. submonilifer Walker, and Anabolia bimaculata (Walker), as determined by identification of adults reared from larvae. One of these species, L. submonilifer, is widespread throughout eastern and northern North America, and adults are common in Ontario. Records for frequency of capture of adults of this species reveal that adults occur from May through October, a situation that led to the interpretation that two generations occur each year in L. submonilifer (Vorhies, 1909; Betten, 1934; Ross, 1944). But intensive field collecting and rearing of limnephilid larvae by Flint (1960) and by me failed to yield larvae from which this second generation could have been derived. For L. indivisus, similar evidence, but v/1th records for adults extending from about June through September, indicated that there was also only one generation each year in that species. Furthermore, dissection of females of these two species, beginning in the summer and autumn of 1960 , indicated that they were not sexually mature until late summer. 
It was evident, then, that there was only one generation each year in these two North American species, and that the adults emerging in spring probably lived through summer to oviposit in autumn in pool basins, thus bridging the height of the drought. Proceeding on this hypothesis, I sought and found egg masses of limnephilid caddisflies in basins of the temporary pools studied, beginning in September, 1960. As indicated in the preceding section, the full explanation for these observations on delayed sexual maturity and oviposition was provided by the fine work of Novak and Sehnal $(1963,1965)$ on diapause.

Each autumn, for several years after discovery of egg masses of temporarypool limnephilids, observations were made on the egg masses in the field and in the laboratory. Egg masses of several species have been found in the dry basins of the pools studied, but efforts to rear larvae from them to a stage where identification could be made have been successful only for Limnephilus indivisus and L. submonilifer. No further observations are available on the life history of Anabolia bimaculata, beyond the fact that relatively small numbers of larvae occur persistently each spring in the temporary vernal pools studied. Our general records for this species indicate that adults occur in southern Ontario from approximately June 21 to August 21. There is no indication of a diapause in the last larval instar, as reported for Anabolia furcata Brauer by Novak (1960).

\section{Observations on Limnephilus indivisus}

Because most observations pertain to L. indivisus, this account of oviposition and eggs will be based on that species. All available observations on $L$. submonilifer are in agreement.

Eggs are encased in a clear, gelatinous matrix, 6-10 $\mathrm{mm}$ in diameter (Fig. 1), essentially globular or ovoid in shape but flattened on the side of attachment to the substrate. The number of eggs in the matrix varies: a globule $6 \mathrm{~mm}$ in diameter contained $154 \mathrm{eggs}$; another, approximately $9 \mathrm{~mm}$ in diameter, contained 258 eggs. Females usually deposit egg masses close to the soil on the underside of pieces of wood or bark lying in the pool basin or in concavities, thereby gaining the advantage of increased humidity and protection from sun and wind.

In the pools studied in southern Ontario, most oviposition by females of L. indivisus evidently occurs in September, at the earliest probably in late August. In 1962 an experiment was conducted to determine the period of oviposition in one pool (Kendal I). Fifty pieces of wood of various sizes lying in the dry basin were numbered with plastic tags on July 18. By August 25 no evidence of oviposition could be found; by September 12 two clean, fresh, gelatinous globules were present on marked pieces; and by September 30 two more had appeared on marked pieces. The basin of the pool was free of surface water throughout this period, but the surface soil had become more moist as autumn approached. Delay in oviposition brought about through diapause therefore effectively delays oviposition in pool basins until moisture of surface soil and pieces of bark and wood on it has been replenished. In the pools studied, surface of the basin was often dry after several weeks' exposure to summer sun and wind. 


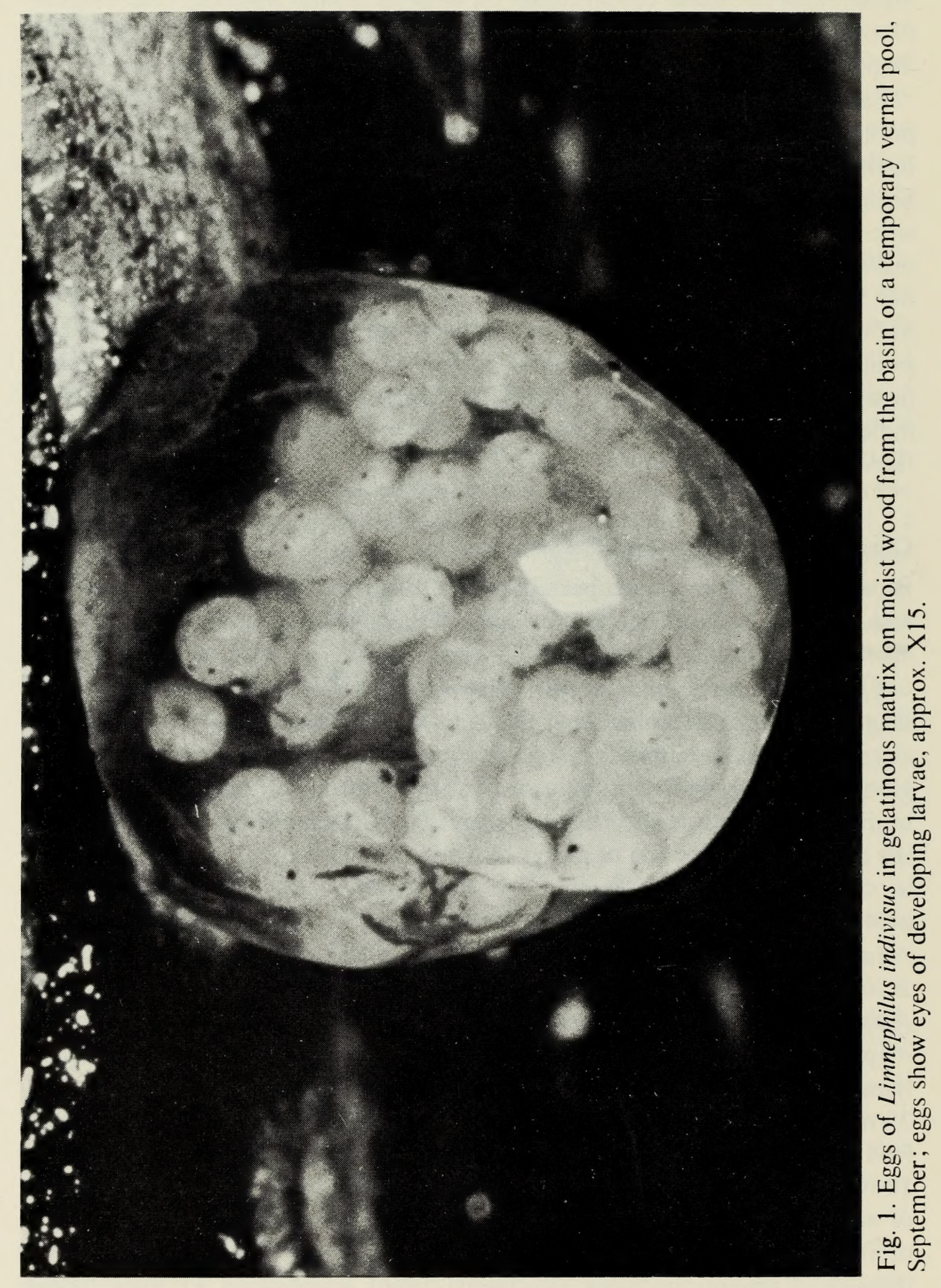




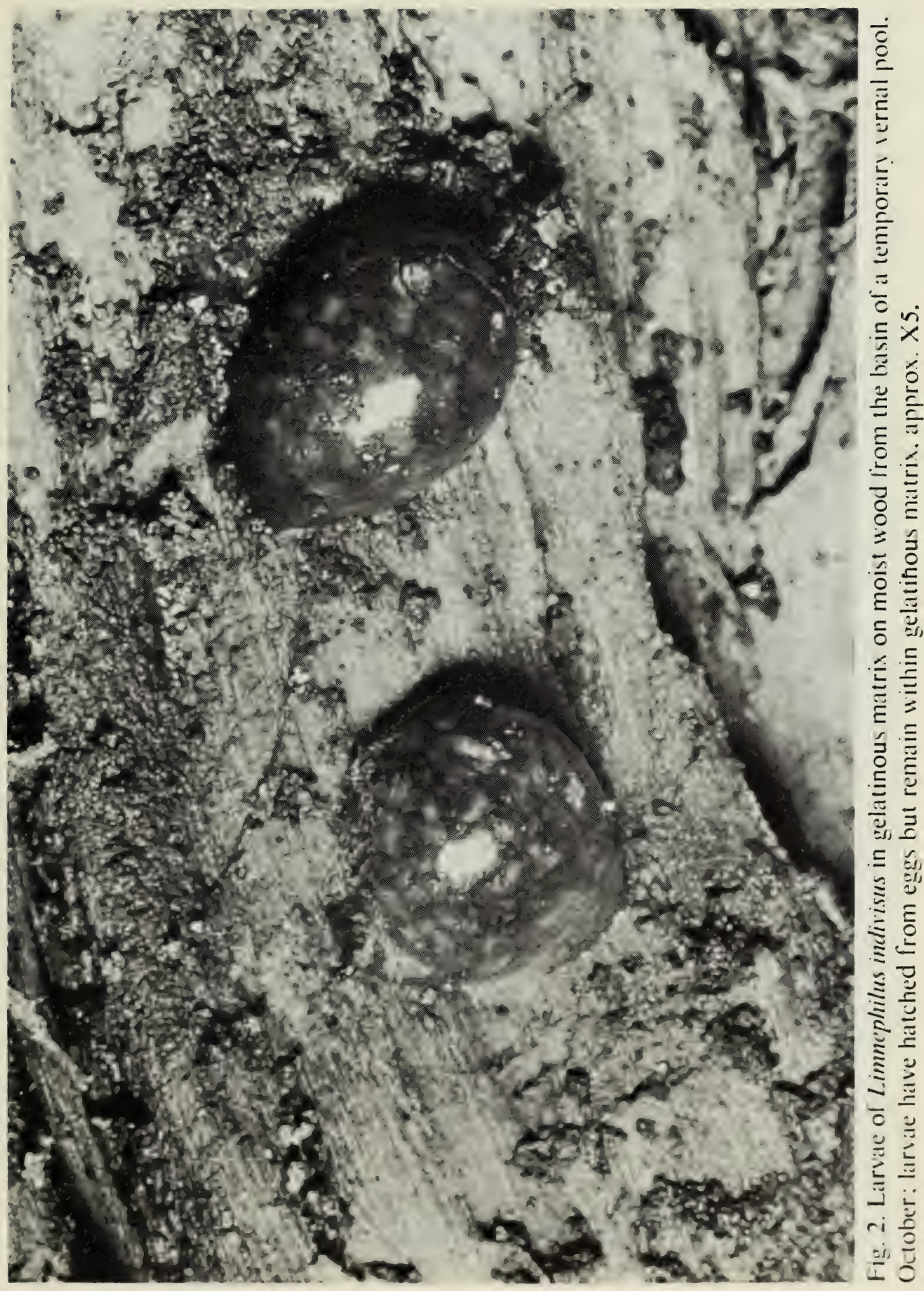




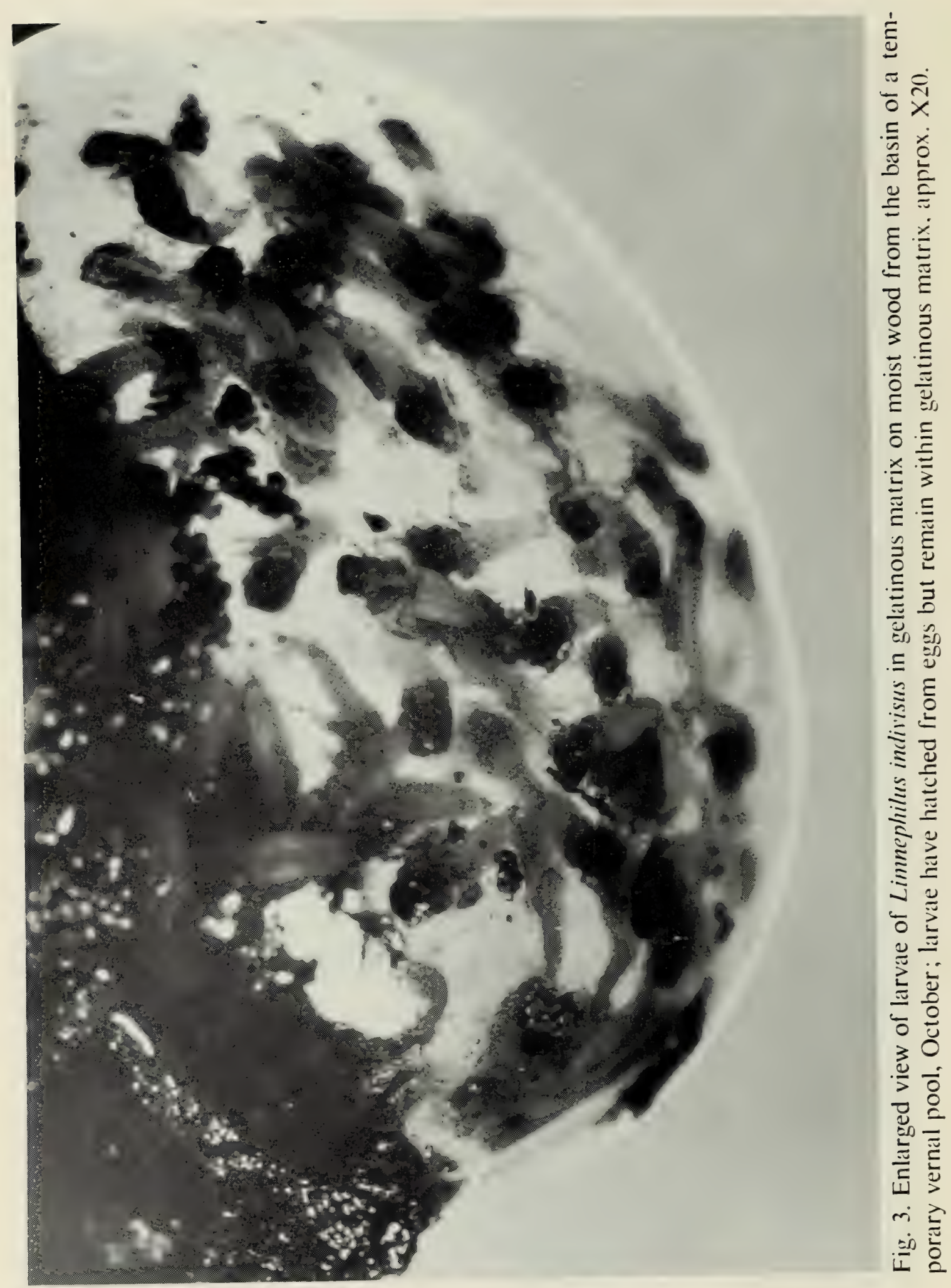




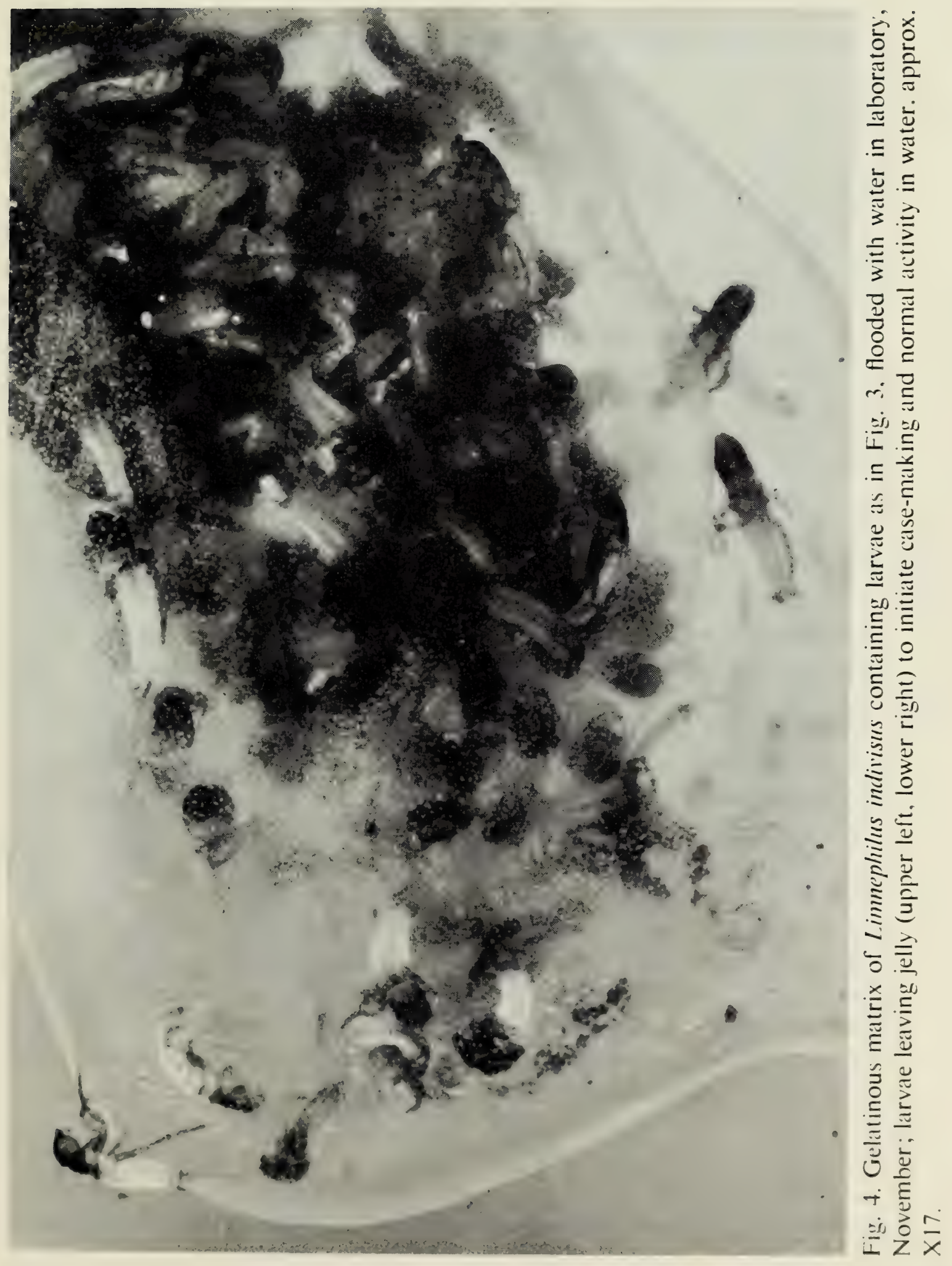


Development of eggs began shortly after oviposition, and even by midSeptember some larvae were fully formed and beginning to rupture the colourless egg chorions, to move slowly about within the gelatinous matrix (Figs. 2, 3). Laboratory experiments with egg masses containıng these active larvae collected in the autumn showed that the larvae remain within the gelatinous matrix until after it is flooded with water. After flooding, larvae leave the jelly (Fig. 4) and construct loosely organized cases from tiny pieces of debris. These observations indicate that in nature if a pool basin retains sufficient surface water in the autumn to flood the gelatınous matrices, larvae of $L$. indivisus can begin free-living existence. In this way the larvae are able to gain an advantage in completing their development before disappearance of the transient waters of the following spring. In confirmation, I collected active early instar larvae of $L$. indivisus in water below the ice of a pool (Kendal I) in November 1959, when it was a temporary autumnal pool; and in water below ice in the same basin in December 1960, when it was a permanent pool.

The majority of pools in this study did not, however, retain surface water until snow melted in March (i.e., they were temporary vernal pools, as defined above). In the absence of surface water to sustain normal activity, larvae of $L$. indivisus remain within the gelatinous matrix throughout the winter. I collected gelatinous globules in January 1961 from protected sites on the undersurfaces of logs that lay in the snow-covered basin of a pool (Vandorf III) that was without surface water throughout the autumn. At an air temperature then below $0^{\circ} \mathrm{C}$, the matrix was firm and frost-covered; brought into the laboratory, it became soft and somewhat fibrous. Exposed to rising temperature indoors, the larvae began slow, writhing movements; flooded with water, they soon left the gelatinous matrix and began to build cases.

In the basin of another temporary vernal pool (Kendal II), gelatinous globules known to contain living larvae of $L$. indivisus in October 1971 were taken from the underside of a log covered with approximately $90 \mathrm{~cm}$ of snow early the following March (Fig. 5). Air temperature at that time was $-4.5^{\circ} \mathrm{C}$, but the temperature $3 \mathrm{~cm}$ below the surface of the soil of the pool basin was $1^{\circ} \mathrm{C}$. Some invertebrates were moving actively on the underside of the log near the gelatinous matrices - a snail, a mite, and a flatworm. A few matrices were no longer globular because the gelatinous material had become less viscous and had spread into an amorphous patch. Other matrices retained much of their original globular appearance but were somewhat irregular (Fig. 6). When the gelatinous matrices were brought into the laboratory and placed on a damp paper towel in a petri dish, larvae immediately began to leave the matrices and crawl away (Fig. 6); when flooded with water, the larvae began to build cases. The basin of this pool was without surface water from about June until late March, but judging by observations made in previous years, the egg masses were probably deposited in September. They were inspected on several occasions in October and November before snow covered the ground in December. The larvae remained alive in the gelatinous matrix throughout the winter - a total of about 7 months after oviposition. Early instar larvae of $L$. indivisus were seen in this pool in April and continued normal development to emerge as adults before the pool dried up. 
The gelatinous matrix surrounding the eggs of caddisflies ovipositing beneath the water surface is softer and more fluid than that of limnephilid species ovipositing in the dry basins of temporary pools. The important functional difference between these two types of gelatinous matrix was demonstrated by a simple experiment. In Algonquin Park, a limnephilid egg mass (species unknown, but the physical appearance of gelatinous matrix was similar to that of L. indivisus) taken from a temporary-pool basin lacking surface water was placed on damp soil in a covered petri dish. Beside it was placed a phryganeid egg mass of the typical doughnut shape collected from beneath the water of a permanent pond. After 7 days the gelatinous matrix of the phryganeid egg mass had lost its water and lay on the surface of the soil as a thin film. Three days later larvae hatched from the eggs on the surface of the soil but were moribund and apparently severely hampered in their attempts to crawl from the sticky remnants of the gelatinous matrix. Exposed to the same conditions, the limnephilid egg mass retained its shape and moisture, as indeed other similar matrices with these characteristics do in nature for several months.

Contrasted with some limnephilid species that normally oviposit above permanent water, L. indivisus has several other distinctive features. On several occasions I found limnephilid egg masses on plants above the surface of permanent waters (August, 1970, 1972; Itasca State Park, Minnesota): on two emergent stems of Eleocharis sp. approximately $30 \mathrm{~cm}$ above the surface of a marshy pond; and on Asclepias sp. rooted on shore but overhanging the edge of a slow marshy stream connecting two lakes, approximately 100 $\mathrm{cm}$ above the water surface. These egg masses were elongate, approximately $30 \mathrm{~mm}$ long and $10 \mathrm{~mm}$ wide, with the cloudy, opaque, cream-coloured matrix somewhat soft and strongly furrowed, much as described for Nemotaulius punctatolineatus (Silfvenius, 1906). Larvae reared from them to the second instar, when they died, indicate that the species involved is probably Nemotaulius hostilis (Hagen). In any event, when larvae hatched from the eggs a few days after being brought into the laboratory and began to crawl about within the matrix, the gelatinous material became noticeably more fluid. Larvae in the matrix attached to two stems of Eleocharis sp., without assistance reached water $15 \mathrm{~cm}$ below in a pan in which the stems had been fixed in an upright position. With increasing activity by the larvae, and in the absence of rain or similar stimulus, the matrix thinned and spread gradually downward toward the water as a thin layer between the two stems. Thus, the liquefaction of matrices deposited above permanent water, to which the activity of newly hatched larvae evidently contributes, appears to facilitate entry of larvae into the water. Contrasted with these matrices are the transparent, colourless, and firm matrices of $L$. indivisus that do not liquefy, even though autumn temperatures would seem to permit some larval activity within them for a period before the onset of low temperatures. Furthermore, larvae of $L$. indivisus show little inclination to leave the matrix even when they are active, providing it is not flooded with water.

Eggs of $L$. indivisus appear to be unusual, at least in the subfamily Limnephilinae, in continuing embryonic development under water. Matrices with eggs showing red, larval eye spots on the embryos, collected from dry parts in the basin of a pool (Vandorf, unnumbered; September 1969) were 


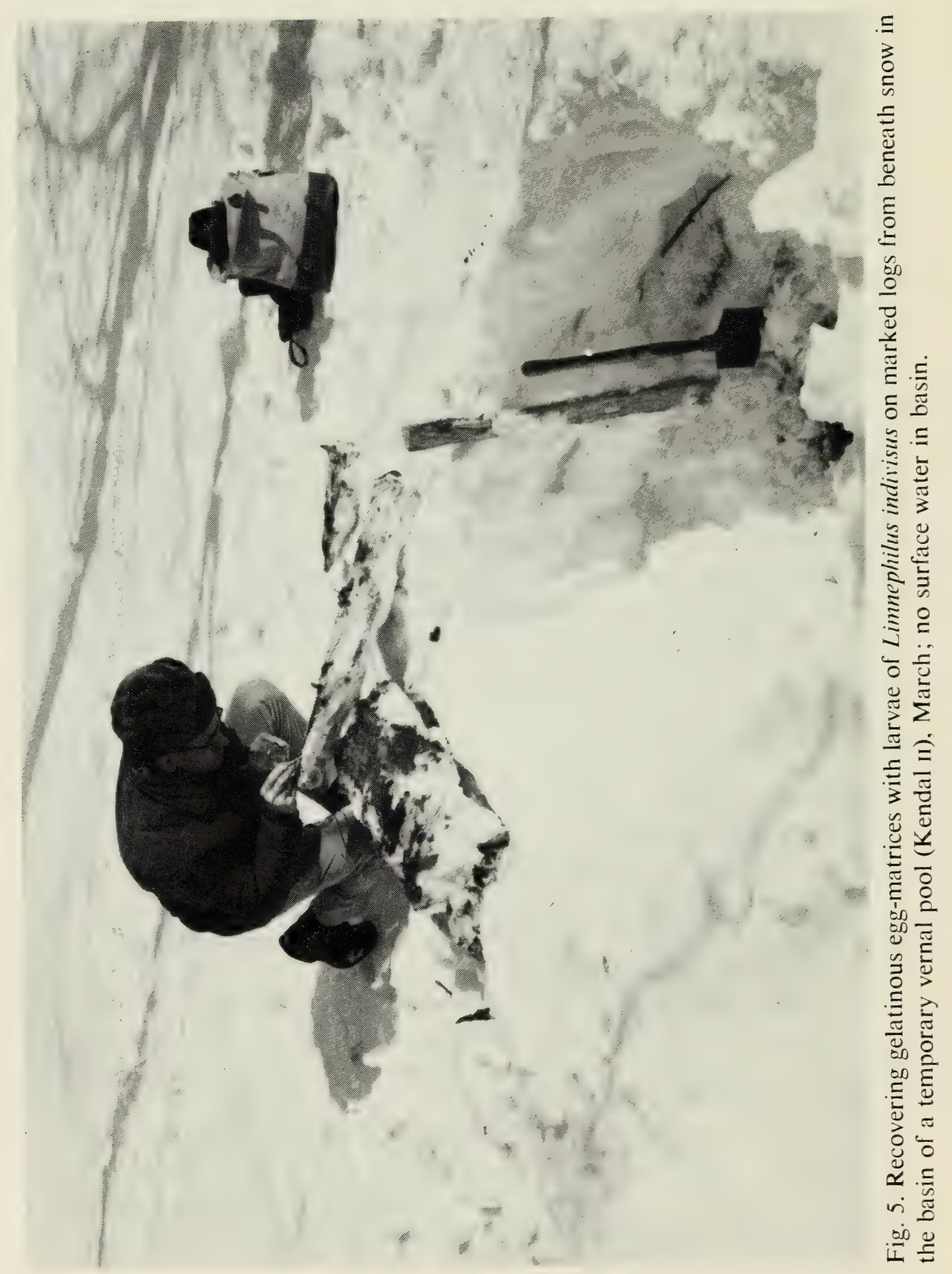




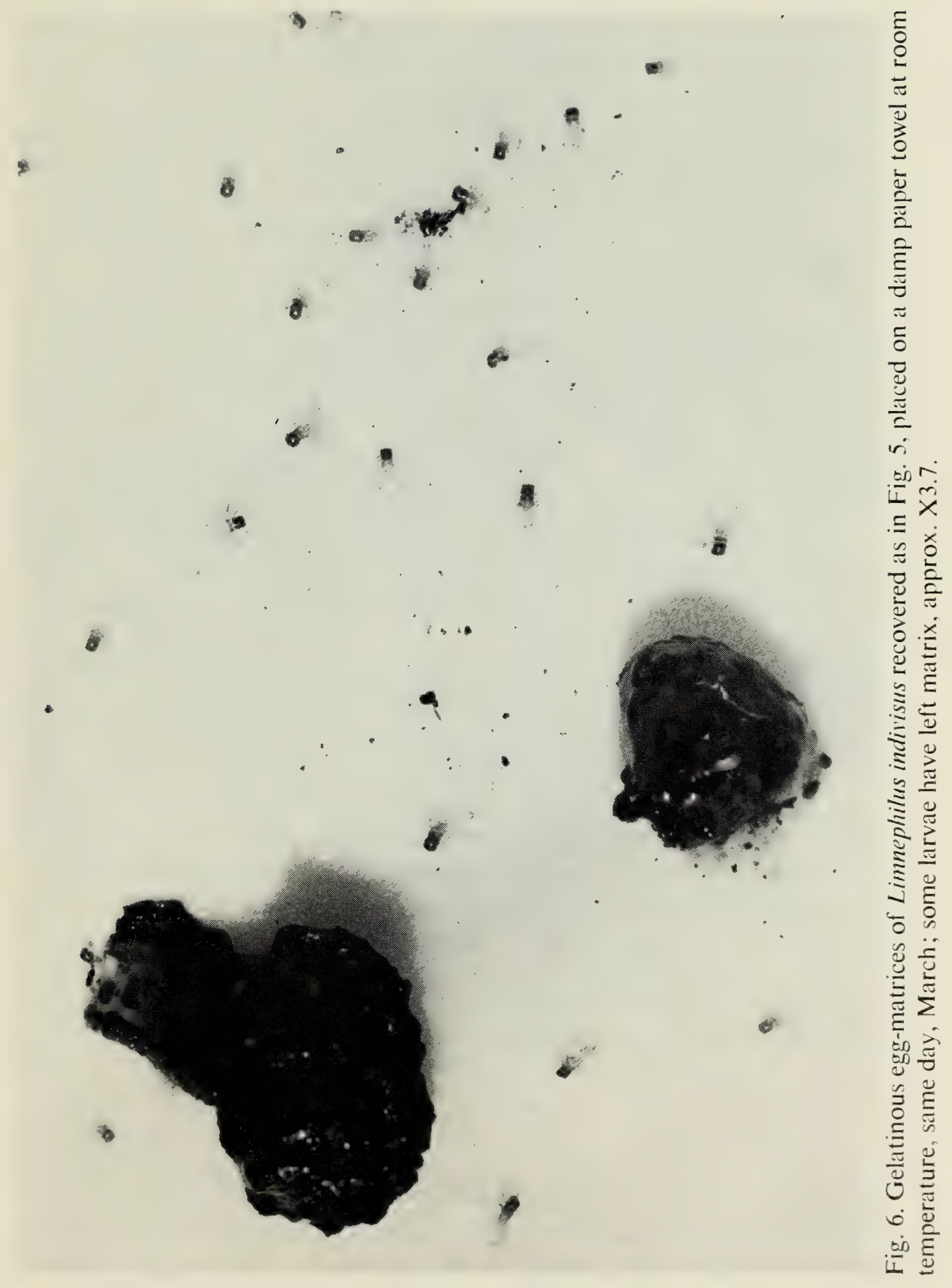


flooded with distilled water in the laboratory and placed in a refrigerator at $6^{\circ} \mathrm{C}$. Development to hatching of most of the eggs within the matrix was about 2 weeks later than the control egg mass placed on a damp paper towel, but flooding had no apparent effect on ultimate development. On the other hand, eggs of Frenesia spp. deposited above the surface of permanent water were reported to cease development when submerged for more than one day (Flint, 1956); and embryos of Nemotaulius punctatolineatus were said to cease development and die when submerged in water (Silfvenius, 1906). Further studies are under way to obtain more precise comparative data on the structure and properties of limnephilid egg matrices.

Observations on Limnephilus stigma Curtis and L. rhombicus (Linnaeus) made by Novak and Sehnal $(1963,1965)$ are in agreement with those offered here for $L$. indivisus and L. submonilifer: deposition of egg masses in moist places in the dry basins of pools; partial submergence of egg masses retards development of embryos but does not cause their death; larvae leave the gelatinous matrix when it is completely flooded. They also found that egg masses would not develop if placed on substrates that were too dry, which probably explains my finding of a few matrices with embryos only partially developed in late autumn, when other matrices in the same basin and evidently of the same species contained fully-developed larvae.

Wesenberg-Lund (1913) stated that larvae of Nemotaulius punctatolineatus (Retzius) fed upon empty egg chorions while still within the gelatinous matrix. My observations provide no specific information on feeding, but chorions were present in the gelatinous matrices of Limnephilus indivisus even after larvae had been moving within them for 6 months in a refrigerator at a temperature of approximately $6^{\circ} \mathrm{C}$.

It is concluded, then, that the species $L$. indivisus and L. submonilifer are primarily adapted for life in temporary vernal pools through mechanisms that delay or suspend development of their immature stages until soil moisture or surface water in the basins is sufficient to sustain eggs or larvae. After emergence of the adults in spring, oviposition is postponed for approximately 3 months until late summer or early autumn because sexual maturity is delayed, largely through photoperiod-controlled diapause. Oviposition is independent of surface water, requiring only a moist substrate. Larvae develop and hatch from the eggs but remain within the gelatinous egg-matrix until pool basins are flooded with water the following spring. Properties of the gelatinous egg-matrix are therefore responsible for protecting eggs and larvae from desiccation and from freezing for periods up to 7 months.

For the Trichoptera as a whole, adaptations exemplified by L. indivisus and $L$. submonilifer, and evidently by $L$. bipunctatus as well (Décamps, 1967), must be regarded as unusual and the properties of their gelatinous egg matrices altogether remarkable. Still to be investigated are the means by which gaseous exchange is effected through the gelatinous matrices surrounding caddisfly eggs deposited apart from water - a problem to which Hinton (1969) has referred. Probably there are many species in this family with life histories similar to these species of Limnephilus, but they cannot yet be recognized because of the lack of observations on the over-wintering viability of their larvae in basins of known temporary vernal pools. There are also many species in this family in which the life histories show few of these modifica- 
tions. These strong contrasts provide the basis for comparative systematic data that could yield unusual insights into evolution within the Limnephilidae. Existing data on oviposition sites and egg matrices are limited but will now be examined.

\section{Review of data on oviposition for the Limnephilidae}

The Limnephilidae are one of the largest families of the Trichoptera and occur on every continent except Antarctica. More than 700 species are listed in a review and classification of the world fauna by Schmid (1955). Although many new species have been discovered since that time, a useful index of the relative size of each subfamily is provided by Schmid's data: Apataniinae, 71 species; Dicosmoecinae, 85; Drusinae, 42; Limnephilinae, 400; Neophylacinae, 34; and Pseudostenophylacinae, 50.

\section{Apataniinae}

Nielsen (1942) found that females of Apatania muliebris McLachlan fastened egg masses to rocks a few centimetres below the water surface. Elliott (1971) observed that females of this same species either release an egg mass into the water while flying over it or crawl down a large rock to leave an egg mass adhering to a stone beneath the water surface. Dr. L. Botosaneanu, Bucharest, informed me (in litt.) that he observed similar habits of oviposition for A. carpathica Schmid and A. motasi Botosaneanu.

\section{Dicosmoecinae}

No published data on oviposition are available, but some observations were made during one of our field expeditions in Oregon (Metolius River) in September 1966. Females of Dicosmoecus atripes (Hagen) taken at a black light were placed in large jars half-filled with water, with a rock protruding above the water surface. Several females soon crawled down the rock, submerged several centimetres below the water surface, and remained there. Some were dead in the morning, but one had deposited eggs in a gelatinous matrix on the rock at the water line. The matrix, partly in and partly above the water, was amorphous in shape and of about the same consistency as phryganeid egg matrices. Similar egg masses were later found on objects along the water's edge, always partly or wholly submerged. Observations made by Mr. R. J. Ellis on oviposition of this same species in Alaska (in litt.) are in general agreement.

\section{Drusinae}

This subfamily is not represented in North America, but a detailed study by Gower (1966) of the European species Drusus annulatus (Stephens) showed that eggs are deposited beneath the water surface. Egg masses of Ecclisopteryx guttulata (Pictet) were found by Nielsen (1942) on the undersides of stones submerged in a brook in Denmark. Dr. Botosaneanu (in litt.) informed me that he observed eggs of species of Drusus and Ecclisopteryx beneath the water surface in Romania. 


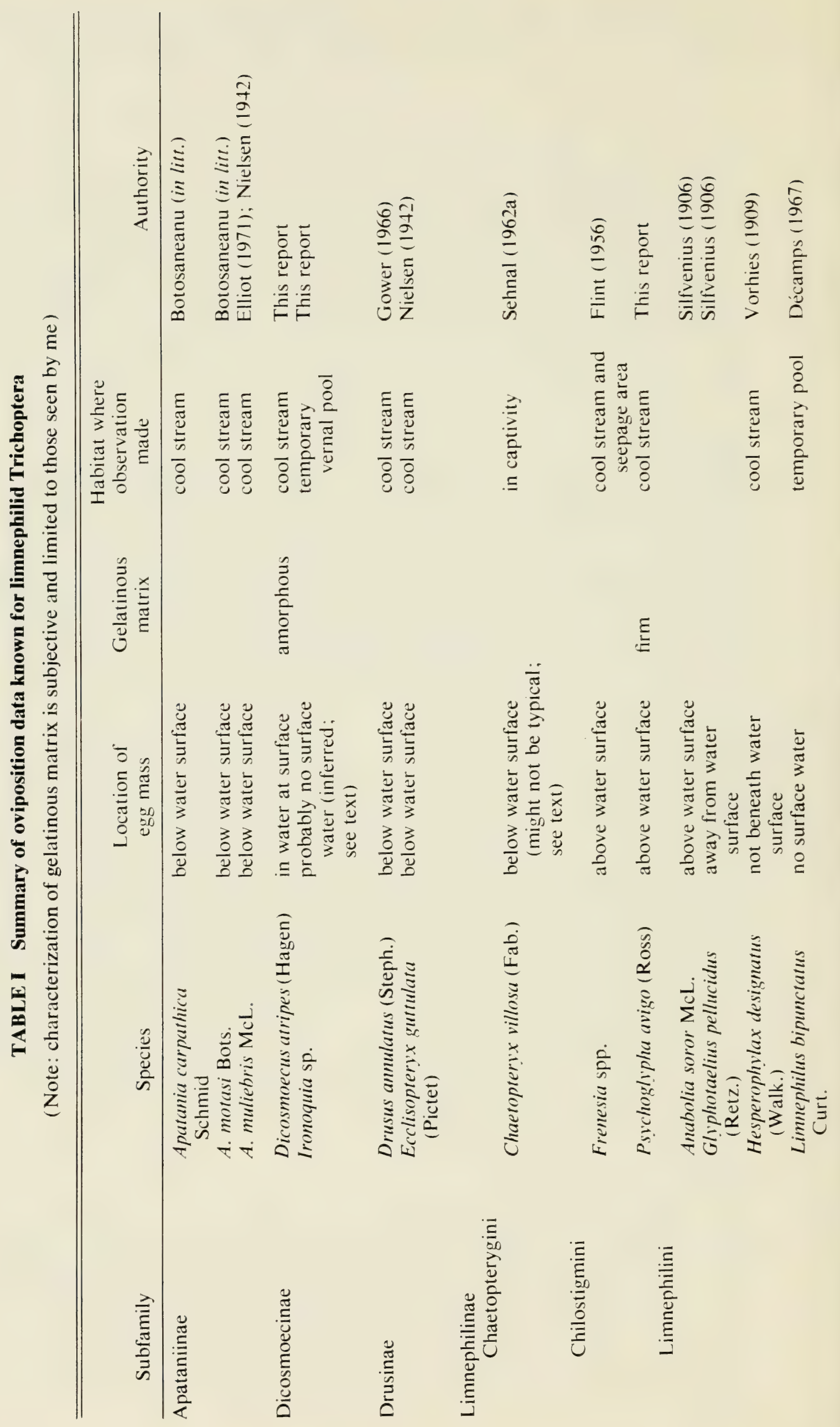




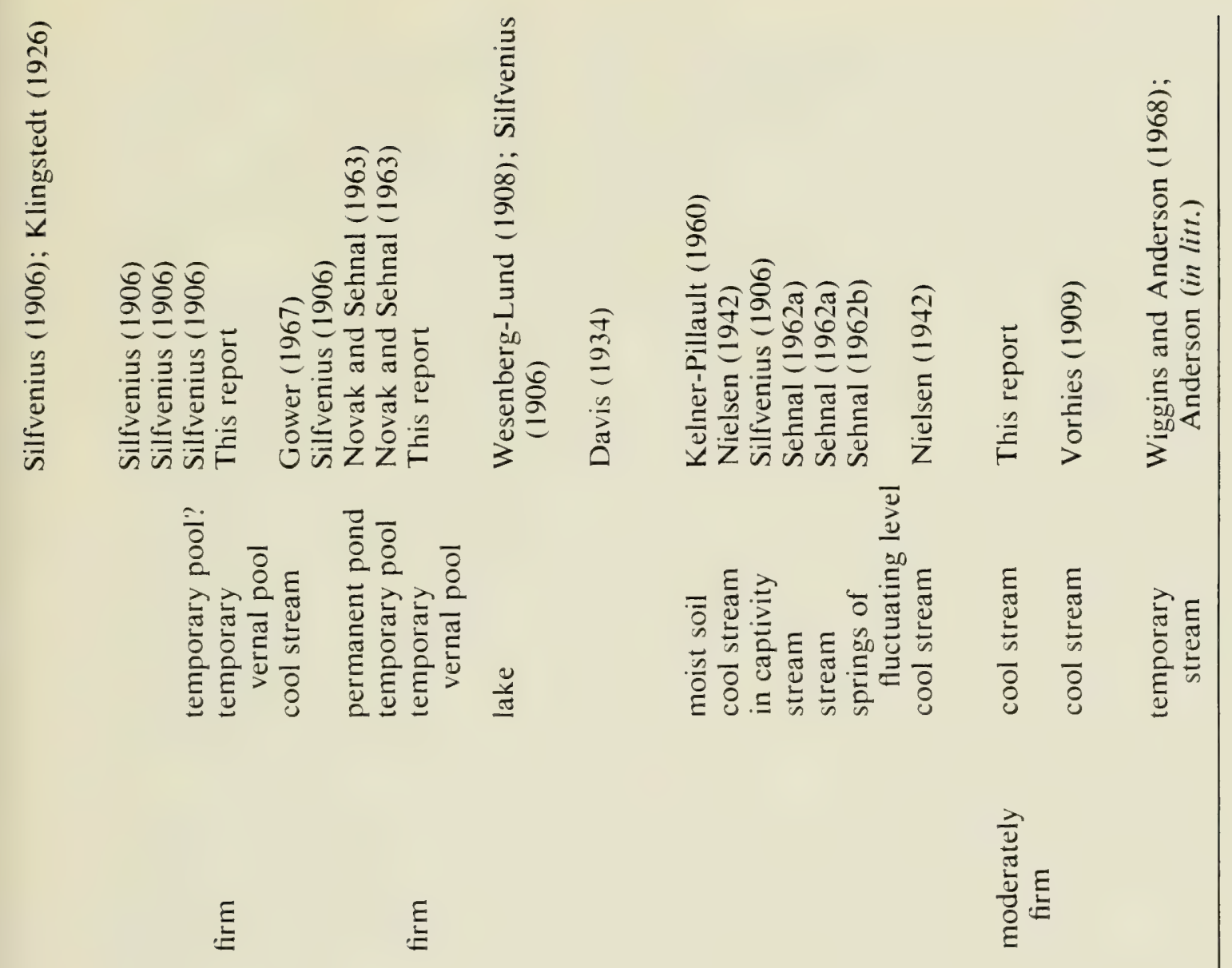

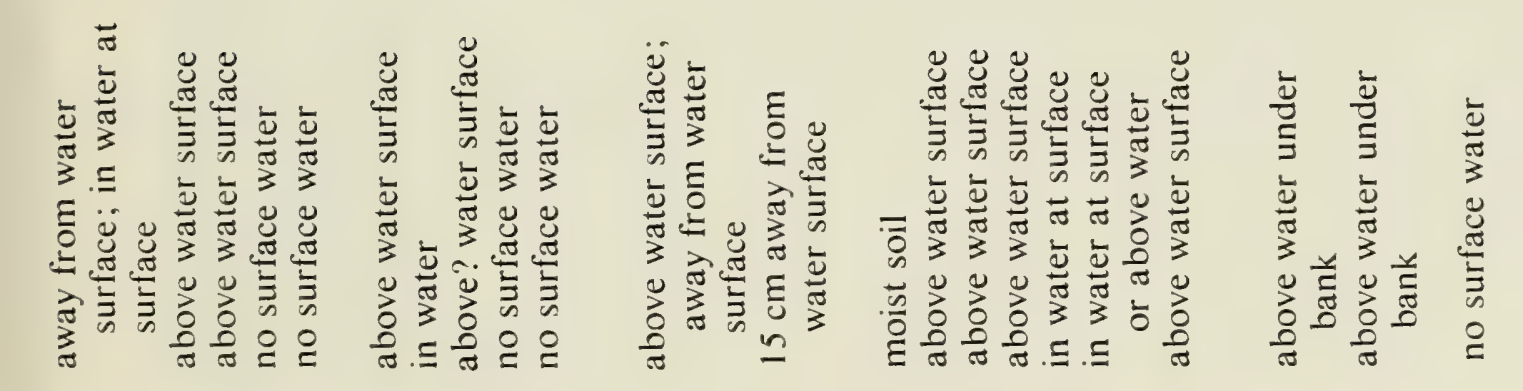

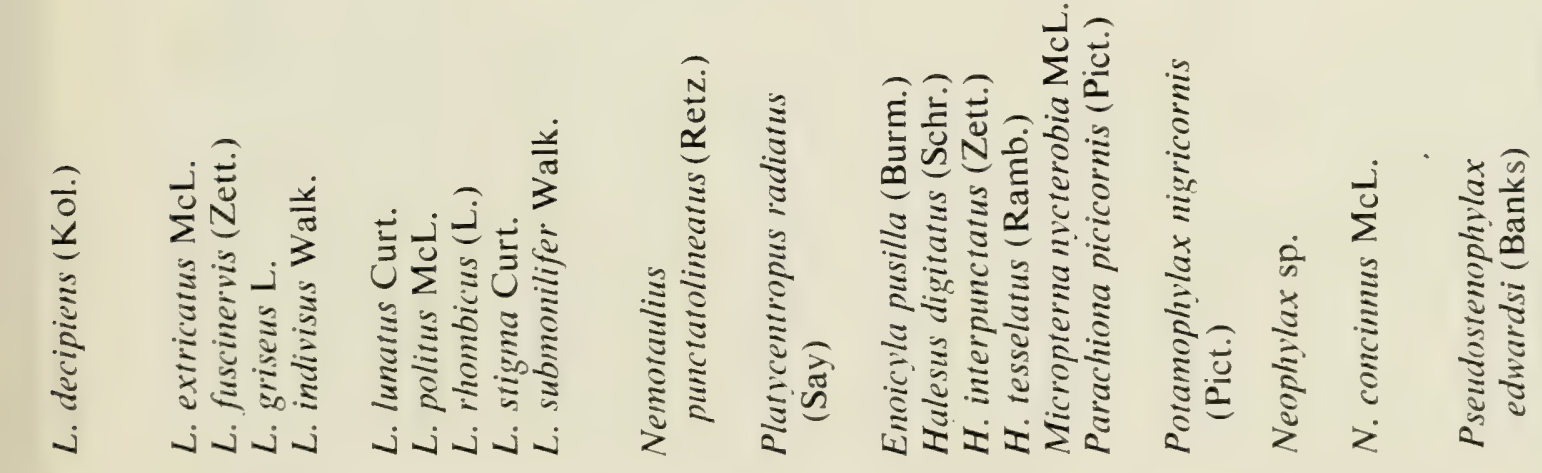
㙜

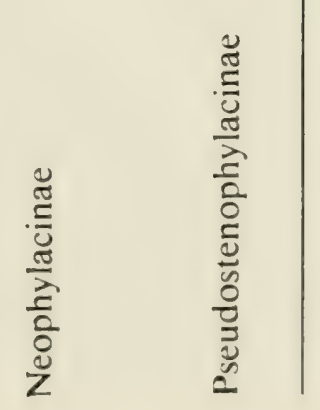




\section{Limnephilinae}

For this subfamily, many more observations concerning oviposition are available. In the tribe Stenophylacini, Sehnal (1962a) observed oviposition in water at the surface by female Micropterna nycterobia McLachlan but above the water surface by female Halesus tesselatus (Rambur). Oviposition above the water surface is also known for Halesus digitatus (Schrank) (Nielsen, 1942) and Halesus interpunctatus (Zetterstedt) (Silfvenius, 1906). Eggs of the terrestrial species Enoicyla pusilla (Burmeister) are deposited on moist soil beneath trees where larvae are found (Silfvenius, 1906; Balduf, 1939; Kelner-Pillault, 1960). Eggs of Philocasca demita Ross (Anderson, 1967; Wiggins and Anderson, 1968) are also probably deposited away from water, since the larvae occur in terrestrial situations. Nielsen (1942) believed that eggs he found deposited above the water surface of a spring in Denmark were those of Potamophylax nigricornis (Pictet). Sehnal (1962b) found egg masses of Parachiona picicornis (Pictet) in water at the surface or above water.

For the Chaetopterygini, Sehnal (1962a) observed in the laboratory oviposition beneath the water surface by female Chaetopteryx villosa (Fabricius) but stated that this behaviour might not be entirely typical of that species in nature.

For the Chilostigmini, Flint (1956) found oviposition above the water surface to be characteristic for species of the North American genus Frenesia. We reared to the adult stage larvae of Psychoglypha avigo (Ross) that hatched from an egg mass collected about $15 \mathrm{~cm}$ above the water surface of the Metolius River in Oregon.

For the Limnephilini, Novak and Sehnal (1963) found eggs of Limnephilus stigma Curtis on damp objects in the basins of temporary pools from which all surface water had disappeared. The same authors also found eggs of L. rhombicus (Linnaeus) on the bank of a small pond up to $10 \mathrm{~cm}$ from the edge of the water. Eggs of several other European species of Limnephilus were also reported to be deposited above the water surface (Silfvenius, 1906): L. lunatus Curtis, L. extricatus McLachlan, and L. fuscinervis (Zetterstedt). Egg masses of $L$. decipiens (Kolenati) were found away from the water surface by Silfvenius (1906) but were reported from beneath the water surface by Klingstedt (1926). Egg masses of L. politus McLachlan were found in water by Silfvenius (1906). Gower (1967) found eggs of Limnephilus lunatus Curtis attached to stones and leaves of watercress $1-14 \mathrm{~cm}$ above the water surface. Egg masses of L. bipunctatus Curtis were found in basins of temporary pools where there was no surface water (Décamps, 1967), and those of Glyphotaelius pellucidus (Retzius) were found away from the water surface (Silfvenius, 1906). My observations on eggs of L. indivisus and L. submonilifer deposited in the basins of temporary pools from which surface water had disappeared were outlined earlier in this paper. It is known that female Nemotaulius punctatolineatus (Retzius) oviposit above the water surface (Silfvenius, 1906; Wesenberg-Lund, 1908, 1910), as do females of Anabolia soror McLachlan (Silfvenius, 1906). Egg masses of Hesperophylax designatus (Walker) were found under stones but not beneath the water surface by Vorhies (1909). Eggs of Platycentropus maculipennis (Kolenati) [syn. of $P$. radiatus (Say)] were found $15 \mathrm{~cm}$ away from water (Davis, 1934). 


\section{Neophylacinae}

Few published observations are available. Patten (1884) described the eggs of a species, said to have been identified by Hagen from both males and females as Neophylax concinnus McLachlan, and stated that gelatinous masses containing eggs were abundant on the bottom of a stream in water $10-13 \mathrm{~cm}$ deep. Vorhies observed (1909) that egg masses of Neophylax autumnus Vorhies were deposited above the water surface "in well protected places beneath overhanging banks." The conflict between these two observations is noteworthy because $N$. autumnus Vorhies was designated a junior synonym of $N$. concinnus McLachlan by Kimmins and Denning (1951). Patten's (1884) observations, often cited elsewhere, as in Ulmer (1925), may have been based on a mistaken association of the eggs, for my observations agree with those of Vorhies. I collected five gelatinous masses containing Neophylax sp. larvae and eggs showing larval eye spots along a small rapid stream (Credit River system, Peel County) in southern Ontario in October 1971. All egg masses were deposited above the water line on fine roots lining the roof of small cavities under the stream bank. Egg masses were some $2-5 \mathrm{~cm}$ directly above the water that ran beneath the bank at that point. So positioned, egg masses were exposed to a consistently high humidity and completely protected from drying sun and wind. The gelatinous matrix seemed to be thinner and stickier than that of species such as Limnephilus indivisus that oviposit in the complete absence of surface water, as outlined above. Observations made by Mr. F. O. Howard in Michigan (in litt.) on egg masses of Neophylax sp. are in general agreement. The occurrence of larvae of certain species of Neophylax in streams that become dry in summer (Ross, 1944) can probably be explained by oviposition that is apart from surface water. Furthermore, larvae of many species of Neophylax undergo a diapause in the last larval instar before pupation. This larval diapause appears to afford species of Neophylax in temporary streams the same advantage of postponing oviposition until the height of the drought period is over, as does diapause in the adult stage for limnephiline species of temporary pools.

\section{Pseudostenophylacinae}

No published information on oviposition is available. In Oregon, however, larvae of Pseudostenophylax edwardsi (Banks) emerge as adults in April from small, run-off channels that dry as summer progresses (Wiggins and Anderson, 1968). Dr. Anderson advised me that his subsequent observations reveal oviposition in this species to be independent of water. At least one eastern North American species, P. uniformis (Betten), is, however, a resident of cold spring runs, but no observations are available to indicate where the eggs are deposited. Because the majority of species in this family occur in Asia and are still known only in the adult stage, no generalized statement about larval habit can be made.

\section{Summary}

Reviewing these data (Table 1), it is clear that oviposition apart from water occurs in several of the limnephilid subfamilies and is not known in others. But it is in the Limnephilinae that these habits have become most widely 
established, although not completely even among the few species for which observations are available. Possibly correlated with this general observation is the impressive numerical superiority of the subfamily Limnephilinae, the 400-odd species comprising more than half of the entire family. An intriguing possibility arises - that evolution of adaptations permitting oviposition apart from water led to new niches for the Limnephilinae, stimulating adaptive radiation. But a great deal more about the characteristics of limnephiline oviposition has yet to be learned before that possibility can be evaluated. In any event, data demonstrate a general correlation between oviposition in water and restriction of larval habitats to cool, lotic waters (Dicosmoecinae, Apatiniinae, Drusinae) and between oviposition apart from water and an extension of larval habitats to include warm, lentic waters (Pseudostenophylacinae, Limnephilinae). The Neophylacinae appear to be an exception, because species are generally characteristic of cool, lotic waters but oviposition in at least some is apart from water. Larvae of some species of Neophylax, however, inhabit temporary streams.

\section{The Dicosmoecinae in temporary pools}

Although almost all limnephilid caddisflies inhabiting temporary pools are members of the Limnephilinae, there are exceptions in the Dicosmoecinae. This subfamily is well represented in North America with eight genera. For all of them, larvae live in cool, usually lotic waters except one - Ironoquia. Larvae belonging to species of this genus are reported to live in temporary pools or small streams that become dry in summer, as well as in permanent waters (Ross, 1944; Flint, 1958; Lepneva, 1966). Five North American species and one European species are assigned to Ironoquia. It appears, then, that in the northern hemisphere caddisflies of the genus Ironoquia are among the few limnephilid species outside the Limnephilinae and Pseudostenophylacinae whose larvae live successfully in temporary waters. As discussed above, a further exception must be made for some species of the Neophylacinae living in streams that become dry in summer.

Species of the Dicosmoecinae and Limnephilinae appear to have invaded temporary pools independently. But have the adaptations been the same in each group? Evidence suggests that at least some different adaptations are involved.

Observations by Flint (1958) on the life history of Ironoquia parvula (Banks) in a temporary pool in New York show that larvae leave the pool in late spring, presumably in the final instar, and crawl beneath fallen leaves around the edge of the pool. There they evidently aestivate as larvae until late summer, when pupation occurs. Similar observations were recorded by Ross (1944), who also stated that records for adults of this genus are confined to late summer and autumn. Diapause in species of Ironoquia evidently occurs in the last larval instar rather than in the adult as in the Limnephilinae studied by Novak and Sehnal $(1963,1965)$ and by me. The function of delay in the life cycle appears to be the same for species of temporary waters in both the Limnephilinae and Discosmoecinae - suspending development until the drought phase of the seasonal cycle has passed. It may be surmised that adults of Ironoquia spp. become sexually mature soon after emergence and 
that eggs are subsequently deposited on a suitable substrate in the pool basin or stream bed. To my knowledge the egg mass of no species of Ironoquia has been described, and therefore the nature of the gelatinous matrix is not known.

In one of the temporary vernal pools studied by me in southern Ontario (Kendal II), larvae of Ironoquia sp. were found in May 1972. This basin lacked surface water from June of the preceding year through March. It was in this same basin and in the same year that larvae of Limnephilus indivisus in their gelatinous egg-matrices were recovered from beneath snow in March, shortly before the basin filled with water. Therefore, there is indirect evidence to indicate that larvae of at least one species of Ironoquia can remain viable without surface water in the basin of a temporary vernal pool through autumn and winter. It seems probable that properties of the gelatinous egg-matrix will account for this over-wintering viability, as in Limnephilus indivisus, but this has yet to be confirmed.

Even with this limited insight into the means by which some dicosmoecine Trichoptera have exploited temporary pools, it is instructive to examine the fauna of South America, where the Limnephilidae are represented entirely by members of the Dicosmoecinae. Species of several genera endemic to South America occur in montane regions of the southern part of the continent. Temporary pools occur in these same areas. Dr. O. S. Flint advised me (in litt.) that he collected adults and live pupae of Magellomyia pirioni (Navas) and $M$. appendiculata (Ulmer) on the island of Chiloé, off the coast of Chile, in basins of temporary pools from which all surface water had disappeared. His collections were made in October, during early spring at that latitude (Flint, 1970). In Dr. Flint's experience M. appendiculata is the most widelydistributed and abundant limnephilid caddisfly in southern South America, with records of adults from late winter through to early autumn but with no evidence for any bimodal frequency in flight activity. Occurrence of adults in spring and throughout the summer in Magellomyia spp. contrasts sharply with restriction of adults to autumn in Ironoquia spp. and suggests that even within the subfamily there are different adaptations for temporary pools. Further observations on diapause and oviposition in species in the Dicosmoecinae will do much to enlarge our understanding of the evolution of temporary-pool adaptations in the Limnephilidae.

\section{Evolutionary considerations within the Limnephilidae}

Oviposition apart from surface water is clearly derived from the primitive method of oviposition in water that characterizes most other families of Trichoptera, including those considered on other grounds to be the most primitive of the order. For the Limnephilidae alone, oviposition in water is probably also the primitive condition and occurs in at least some species of the Apataniinae, Drusinae, Dicosmoecinae, and Limnephilinae. As oviposition apart from surface water occurs in some species of the Dicosmoecinae, Neophylacinae, Limnephilinae, and Pseudostenophylacinae, it appears that this derivative behaviour has originated independently in several lineages. Evolution within these lineages has brought about some diverse results, now to be considered.

Diapause is apparently so closely associated with oviposition apart from 
water that no attempt will be made to deal with it separately in this section. It has already been seen that diapause in groups within the Limnephilidae is operative at different stages in the life cycle. In certain groups of this family, where oviposition in water occurs, diapause appears not to be operational at all. And even in some genera characterized by oviposition above permanent water, such as Nemotaulius and Frenesia, there is no evidence that diapause occurs.

At the very least, oviposition apart from surface water involved: (1) modification of the gelatinous egg-matrix to retain its moisture content for several days or weeks in the absence of any direct contact with surface water; and (2) modification of the response to oviposition sites to elicit egg deposition in humid locations above water. This is a gross simplification of a phenomenon that surely involves a far larger set of characters, but it does correspond to the ovipositional characteristics of Neophylax spp., described above. Perhaps this group represents an early stage in the evolution of oviposition apart from surface water.

Further evolution of oviposition apart from water appears to have led to exploitation of temporary pools - a rich habitat denied to most Trichoptera. Again over-simplifying, this further evolution seems to have involved: (1) modification of properties of the gelatinous egg-matrix to provide protection from desiccation and freezing for eggs and larvae for periods to 7 months without surface water; (2) modification of sensory mechanisms to permit selection of oviposition sites entirely lacking in surface water but destined to become pools weeks or months in the future; (3) increase of larval tolerance and rate of development through a wide range of water temperatures and oxygen levels. These characteristics of the life cycle of Limnephilus indivisus are adapted for conditions in temporary vernal pools as described earlier in this paper. This species appears to represent an advanced evolutionary level of oviposition apart from water.

Re-emergence of caddisfly larvae as terrestrial insects has probably come about through evolution of oviposition apart from water. Species in two genera of the Stenophylacini are known to have terrestrial larvae: (1) eggs of Enoicyla pusilla are deposited on moss or moist soil in a gelatinous matrix (Kelner-Pillault, 1960); (2) although larvae of Philocasca demita were collected on land (Anderson, 1967), eggs have not been found. Failure of limnephilid Trichoptera to exploit terrestrial habitats more widely, even after ovipositional problems had apparently been solved, suggests that other factors inhibit evolution of terrestrial larvae in the Trichoptera. Retention of adequate moisture levels by larvae on land may be one such factor.

Whatever the circumstances that may have brought about establishment of oviposition apart from water in the Limnephilidae, these are some of the more widely separated evolutionary derivatives that present knowledge enables us to identify. Species such as Nemotaulius punctatolineatus and Frenesia spp., in which egg masses are deposited on substrates above the surface of permanent waters, represent other derivatives. Species able to complete their life cycle in temporary autumnal pools are not necessarily able to survive in temporary vernal pools and may represent still other stages in the evolution of oviposition apart from water. Additional evidence may 
enable us to interpret the evolutionary pathways through which these groups have been derived.

Limnephilid species adapted to temporary vernal pools probably ought not to be regarded as specialized for these unusual conditions to a degree that restricts their colonization of other habitats. Larvae of $L$. indivisus and L. submonilifer also occur in a wide variety of permanent ponds and marshes. To the extent that these species are representative of others in temporary pools, adaptations to transient waters appear, then, to broaden their potential for exploiting a wider range of lentic habitats. The mechanisms involved operate equally well in both permanent and temporary waters.

\section{Phryganeidae}

The only non-limnephilid European species involved in the study on diapause by Novak and Sehnal $(1963,1965)$ was a phryganeid, Trichostegia minor (Curtis), the sole member of its genus. These authors found that sexual maturity in adults was delayed by diapause until late summer, in the same manner as for the limnephilids studied. They stated that delay in sexual maturity enables $T$. minor to inhabit temporary pools. But, as in the limnephilid species they studied, pools under observation were evidently temporary autumnal pools, as defined in the present paper. T. minor was recorded from temporary autumnal pools in the Federal Republic of Germany by Wichard and Reichel (1970). Nonetheless, a study of mosquitoes, Aedes spp., in a temporary pool in Denmark (Iversen, 1971) confirms that $T$. minor larvae occur under conditions that are here assigned to a temporary vernal pool.

These observations suggest that an egg matrix with properties similar to those in Limnephilus indivisus has been evolved independently in some species of the Phryganeidae. But, to my knowledge, no observations on eggs of $T$. minor have been published, and confirmation awaits this missing information. In Finland, Silfvenius (1906) found egg masses that he referred to the genus Neuronia with egg masses of Limnephilus sp. under a board in a ditch that was almost dry. Neuronia is no longer a valid genus in the Phryganeidae, and its taxonomic usage has been so variable that it is difficult to interpret this observation. Perhaps Oligotricha striata (Linnaeus) (= ruficrus) - was the species involved, for it is a relatively common species and is recorded as occurring in small pools of fluctuating level (Kreuzer, 1940).

For members of the Phryganeidae in North America, observations made by Mr. F. O. Howard in Michigan (in litt.) reveal that adults belonging to the genus Ptilostomis deposit eggs in August 10-20 cm above the water surface of streams. Gelatinous masses of eggs were attached to the undersides of a $\log$ and of an overhanging bank. The gelatinous matrix was not as firm as that which he found surrounding the eggs of females of the limnephilid genus Pycnopsyche, also deposited above the water surface. Oviposition of Ptilostomis sp. females above water suggests that the gelatinous matrix surrounding their eggs retains moisture when exposed to air for a longer period than the egg matrix of some other phryganeids, such as the one used in the comparative experiment outlined earlier in this paper. Although larvae 
of Ptilostomis spp. usually occur in permanent waters of cool streams and ponds, oviposition by females on moist substrates could enable larvae to invade temporary pools. Perhaps this explains the presence of empty larval cases of Ptilostomis sp. that I found in a temporary pool in May 1960 in Algonquin Park, Ontario. The basin of this pool was without surface water in July of the preceding year, although I do not know whether surface water was replenished in autumn or spring. I also found living, first-instar, phryganeid larvae (genus unknown), still within the gelatinous matrix, beneath wet leaves in another pool basin in Algonquin Park in October 1960. This matrix was fluid and amorphous. Although the basin of the pool was damp, there was no surface water. If this basin were replenished with surface water before the gelatinous matrix lost its moisture (i.e., became a temporary autumnal pool), perhaps these larvae would have survived. Evidently, then, larvae of Ptilostomis spp. and perhaps of species in other phryganeid genera can gain access to temporary autumnal pools, although there is still no evidence to show that they do so regularly or are even successful in completing their life cycle under these conditions. In any event, there is yet no clear evidence that the larva of any North American phryganeid can survive conditions of autumn and winter in the basin of a temporary vernal pool.

\section{Polycentropodidae}

One unexpected result of this study was the discovery of Polycentropus spp. larvae in temporary vernal pools. Larvae of P. crassicornis Walker have been identified (Kendal II). Collections by Mr. I. M. Smith near Chaffeys Locks, Frontenac County, Ontario, indicate that $P$. aureolus (Banks) and P. flavus (Banks) can also live in temporary vernal pools.

No previous information on the habitat of $P$. aureolus or P. crassicornis exists in the literature, as larvae of these species have not been described. Larvae of $\boldsymbol{P}$. flavus were reared from the Dead River, Illinois, a marsh-like habitat, evidently of permanent water (Ross, 1944).

For Ontario generally, our records for adults of these three species of Polycentropus are restricted to June and July, suggesting that females mate, oviposit, and die by the end of July. Females of P. crassicornis, collected at black light beside one of the temporary vernal pools (Kendal II, June 19, 1972), had mature ovaries, their abdomens were distended with eggs, and strings of eggs were partially extruded from the genital opening of specimens preserved in alcohol. From these observations, it may be surmised that there is no summer diapause in adults of $P$. crassicornis and that females oviposit in early summer. But no observations are yet available to indicate where eggs are deposited.

If eggs were deposited in the water of the temporary vernal pool or in its basin apart from water, eggs or larvae would have to remain viable up to 9 months before surface water was restored. Or permanent bodies of water could serve as over-wintering sites for larvae of a second generation if the adults dispersed from the receding temporary vernal pool to other sites for oviposition. This explanation would require that adults of this second generation dispersed again to the temporary pools in spring for oviposition. But collections made (September, 1972) in three small permanent ponds in the 
immediate vicinity of Kendal II failed to yield any larvae of Polycentropus. The means by which species of Polycentropus are adapted to temporary vernal pools remain unknown.

\section{Acknowledgments}

This study has been carried on during a number of years as one project in a larger program on the systematics and ecology of Trichoptera. During this period the program has been supported by the National Science Foundation (grants G22135, GB 4021), the National Research Council of Canada (grant A5707), the Canadian National Sportsmen's Show, and the Fisheries Research Board of Canada. Several persons associated with the larger program contributed to this study, and my gratitude for assistance with field work, rearing of caddisflies, and other matters is extended to Messrs T. Yamamoto, I. M. Smith, A. Odum, H. E. Frania, and R. S. Scott. Dr. N. H. Anderson, Oregon State University, facilitated our field work in Oregon in many ways. Field work in Algonquin Provincial Park, Ontario, was based at the W. J. K. Harkness Laboratory of the Ontario Department of Lands and Forests. In Minnesota, field work was conducted from the Lake Itasca Forestry and Biological Station, University of Minnesota.

Permission to cite field observations was kindly given by $\operatorname{Dr} . \mathrm{N} . \mathrm{H}$. Anderson, Oregon State University, Corvallis; Dr. L. Botosaneanu, Institute of Speleology, Bucharest; Dr. O. S. Flint, U.S. National Museum; Mr. R. J. Ellis, Auke Bay Biological Laboratory, U.S. Department of Commerce, Alaska; and Mr. F. O. Howard, Kellogg Biological Station, Michigan State University. For critical reviews of the manuscript, I extend my thanks to Drs. H. H. Ross, L. Botosaneanu, F. Schmid, and P. S. Corbet. Assistance with translation of European literature, always willingly given by the Rev. J. C. E. Riotte, is gratefully acknowledged. Photographs illustrating this paper were taken by Messrs T. Yamamoto (Figs. 1, 2, 4-6) and the late A. Gatti (Fig. 3). 


\section{Literature Cited}

ANDERSON, N. H.

1967 Life cycle of a terrestrial caddisfly, Philocasca demita (Trichoptera: Limnephilidae), in North America. Ann. Ent. Soc. Am., vol. 60 , no. 2 , pp. $320-323$.

BALDUF, W. V.

1939 The bionomics of entomophagous insects. Part II. St. Louis, John S. Swift. 384 pp.

BETTEN, C.

1934 The caddisflies or Trichoptera of New York State. Bull. N.Y. St. Mus., no. 292, pp. 1-576.

BOURNAUD, $\mathrm{M}$.

1971 Observations biologiques sur les Trichoptères cavernicoles. Bull. Mens. Soc. Linn. Lyon, vol. 40, no. 7, pp. 196-211.

('RICHTON, M. I.

1957 The structure and function of the mouth parts of adult caddisflies (Trichoptera). Phil. Trans. R. Soc., ser. B, vol. 241, pp. 45-91.

1961 Observations on the longevity and dispersal of adult Limnephilidae (Trichoptera). Proc. xith Int. Congr. Ent., 1960, band 1, pp. 366-371.

1971 A study of caddisflies (Trichoptera) of the family Limnephilidae, based on the Rothamsted Insect Survey, 1964-68, J. Zool., vol. 163, pp. 533-563.

DAVIS, M. B.

1934 Habits of the Trichoptera. In Betten, C. The caddisflies or Trichoptera of New York State. Bull. N.Y. St. Mus., no. 292, pp. 82-106.

DÉCAMPS, $\mathrm{H}$.

1967 Ecologie des Trichoptères de la vallée d'Aure (Hautes-Pyrénées). Ann. Limnol., vol. 3, no. 3, pp. 399-577.

ELLIOTT, J. M.

1971 The life history and biology of Apatania muliebris McLachlan (Trichoptera). Entomologist's Gaz., vol. 22, no. 4, pp. 245-251.

FLINT, O. S., JR.

1956 The life history and biology of the genus Frenesia (Trichoptera: Limnephilidae). Bull. Brooklyn Ent. Soc., vol. 51, nos. 4 and 5, pp. 93-108.

1958 The larva and terrestrial pupa of Ironoquia parvula (Trichoptera, Limnephilidae). J. N.Y. Ent. Soc., vol. 66, pp. 59-62.

1960 Taxonomy and biology of nearctic limnephilid larvae (Trichoptera), with special reference to species in eastern United States. Entomologica Am., vol. 40, n.s., pp. 1-117.

1970 Life-history studies on Chilean caddisflies (Trichoptera). Yb. Am. Phil. Soc., pp. 312-313.

GOWER, A. M.

1966 The life cycle of Drusus annulatus Steph. (Trich., Limnephilidae) in watercress beds. Entomologist's Mon. Mag., vol. 101, pp. 133-141.

1967 A study of Limnephilus lunatus Curtis (Trichoptera: Limnephilidae) with reference to its life cycle in watercress beds. Trans. R. Ent. Soc. Lond., vol. 119, pt. 10, pp. 283-302.

HINTON, H. E.

1969 Respiratory systems of insect egg shells. A. Rev. Ent., vol. 14, pp. 343-368. 
IVERSEN, T. M.

1971 The ecology of a mosquito population (Aёdes communis) in a temporary pool in a Danish beech wood. Arch. Hydrobiol., band 69, heft 3, pp. $309-332$.

KELNER-PILLAULT, $\mathrm{S}$.

1960 Biologie, écologie d'Enoicyla pusilla Burm. (Trichoptères, Limnophilides). Année Biol., tome 36, fasc. 1-2, pp. 51-99.

KIMMINS, D. E. AND D. G. DENNING

1951 The McLachlan types of North American Trichoptera in the British Museum. Ann. Ent. Soc. Am., vol. 44, no. 1, pp. 111-140.

KLINGSTEDT, $\mathrm{H}$.

1926 Beobachtungen über die Biologie, insbesondere das Eierlegen von Limnophilus decipiens Kol. (Trich.). Notul. Ent., vol. 6, pp. 118-120.

KREUZ.ER, R.

1940 Limnologisch-ökologische Untersuchungen an Holsteinischen Kleingewässern. Arch. Hydrobiol., Suppl., band 10, pp. 359-572.

LEPNEVA, S. G.

1966 Rucheiniki. Tom II, vyp. 2 [Trichoptera. Vol. II, No. 2] Fauna SSSR, n.s., no. 95. Moskva, Izd-vo Nauka. 560 pp. [In Russian].

NIELSEN, A.

1942 Über die Entwicklung und Biologie der Trichopteren mit besonderer Berücksichtigung der Quelltrichopteren Himmerlands. Arch. Hydrobiol., Suppl., band 17, pp. 255-631.

NOVAK, K.

1960 Entwicklung und Diapause der Köcherfliegenlarven Anabolia furcata Br. (Trichopt.). Cas. Csl. Spol. Ent., tom 57, no. 3, pp. 207-212.

NOVAK, K. AND F. SEHNAL

1963 The development cycle of some species of the genus Limnephilus (Trichoptera). Cas. Csl. Spol. Ent., tom 60, no. 1-2, pp. 68-80.

1965 Imaginaldiapause bei den in periodischen gewässern lebenden Trichopteren. Proc. XiIth Int. Congr. Ent., 1964, p. 434.

PATTEN, W.

1884 The development of phryganids, with a preliminary note on the development of Blatta germanica. Q. J. Microsc. Sci., n.s., vol. 24. pp. 549-602.

ROSS, H. H.

1944 The caddisflies, or Trichoptera, of Illinois. Bull. Ill. St. Nat. Hist. Surv., vol. 23, art. 1, pp. 1-326.

SCHMID, F.

1955 Contribution à l'étude des Limnophilidae (Trichoptera). Mitt. Schweiz. Ent. Ges., beiheft 28, pp. 1-245.

SEHNAL, F.

1962a Přispěvek k poznáni biologie několika druhú chrostiku. Sb. Pracé Přir. Fak. Palack. Univ. Olomouci, tom 11, pp. 301-309.

1962b Zur kenntnis von Parachiona picicornis Pict. (Trichoptera). Čas. Čsl. Spol. Ent.. tom 59, no. 2, pp. 142-151.

SILFVENIUS, A. J.

1906 Trichopterologische Untersuchungen. I Über den Laich der Trichopteren. Acta Soc. Fauna Flora Fenn., vol. 28, no. 4, pp. 1-128.

ULMER, G.

1925 Trichoptera. Köcherfliegen. In Schulze, P. Biologie der Tiere Deutschlands. Teil 36. Berlin, Gebrüder Borntraeger. 113 pp. 
VORHIES, C. T.

1909 Studies on the Trichoptera of Wisconsin. Trans. Wis. Acad. Sci. Arts Lett., vol. 16, pt. 1, pp. 647-738.

WESENBERG-LUND, C.

1908 Notizen aus dem Danischen Süsswasserlaboratorium am Fursee. Nr. IV: Über tropfende Laichmassen. Int. Revue Ges. Hydrobiol. Hydrogr., band 1, pp. 869-871.

1910 Über die Biologie von Glyphotaelius punctatolineatus Retz. nebst Bemerkungen über das freilebende Puppenstadium der Wasserinsekten. Int. Revue Ges. Hydrobiol. Hydrogr., band 3, pp. 93-114.

1913 Fortpflanzungsverhältnisse: Paarung und Eiablage der Süsswasserinsekten. Fortschr. Naturw. Forsch., band 8, pp. 161-286.

WICHARD, W. AND H. REICHEL

1970 Zur Trichopterenfauna periodischer Gewässer; Trichopterenstudien zur Duisburger Sechs-Seen-Platte, II. Nachr. B1. Bayer. Ent. jahrgang 18 , nr. 4-6, pp. 57-58.

WIGGINS, G. B.

1959 A method of rearing caddisflies (Trichoptera). Can. Ent., vol. 91, no. 7, pp. 402-405.

WIGGINS, G. B. AND N. H. ANDERSON

1968 Contributions to the systematics of the caddisfly genera Pseudostenophylax and Philocasca with special reference to the immature stages (Trichoptera: Limnephilidae). Can. J. Zool., vol. 46, no. 1, pp. 61-75. 



